\title{
Southernmost Finding of Lymnaea viatrix Orbigny, 1835 (Pulmonata: Lymnaeidae), Intermediate Host of Fasciola hepatica (Linnaeus, 1758) (Trematoda: Digenea), in Urban and Rural Areas of Patagonia, Argentina
}

\author{
Florencia Kleiman ${ }^{+}$, Silvia Pietrokovsky, W Lobato Paraense*, Cristina Wisnivesky-Colli
}

\author{
Unidad de Ecología de Reservorios y Vectores de Parásitos, Departamento de Ecología, Genética y Evolución, Facultad de \\ Ciencias Exactas y Naturales, Universidad de Buenos Aires, Ciudad Universitaria, Pab. II, C1428EHA, Buenos Aires, Argentina \\ *Departamento de Malacología, Instituto Oswaldo Cruz-Fiocruz, Rio de Janeiro, RJ, Brasil
}

We report the first finding of Lymnaea viatrix south of parallel $41^{\circ} S$, in rural and urban areas from Argentina. Ninety snails were collected during year 2000, from a concrete pond at a Public Square in El Bolsón Village, Río Negro province, and 811 snails in November 1999, and during 2000 from waterbodies within a farm at Cholila locality, Chubut province. Fasciola hepatica infection was detected in $0.9 \%$ snails from the rural area. We discuss the potential risk of L. viatrix to public health in urban areas and its epidemiological importance in rural areas of the Andean Patagonian region.

Key words: Lymnaea viatrix - distribution range - Argentina

Snails of genus Lymnaea are the intermediate hosts of Fasciola hepatica, a parasite of veterinary and public health worldwide importance (Mas-Coma et al. 1995, 1999).

In Argentina, the epidemiological relevance and geographical distribution of these snails are not precisely known and there is considerable taxonomic uncertainty among the species of the genus. Lymnaea diaphana King, 1830 and Lymnaea plicata Hylton Scott, 1953 have been scarcely cited (Hubendick 1951, Hylton Scott 1953), while information on Lymnaea columella Say, 1817 and Lymnaea viatrix is more abundant and up-dated. According to available literature the distribution of $L$. columella is restricted to the Northeast of the country (Castellanos \& Landoni 1981, Paraense 1982, Prepelitchi et al. 2003). L. viatrix was documented in the following provinces: Salta, Jujuy (Castellanos \& Landoni 1981), Buenos Aires (Castellanos \& Landoni 1981, Venturini \& Fonrouge 1985), Corrientes (Lombardero et al. 1979), San Luis (Castellanos \& Landoni 1981, Rossanigo et al. 1983), Córdoba, Entre Ríos, Neuquén, Mendoza (Castellanos \& Landoni 1981, Paraense 1982), and its southernmost distribution was recorded in the locality of Viedma $\left(40^{\circ} 50^{\prime} \mathrm{S}, 63^{\circ} \mathrm{O}\right)$ at the east of Río Negro province (Paraense 1976) (Fig. 1).

In this work we report the presence of $L$. viatrix south of parallel $41^{\circ} \mathrm{S}$, in an urban area of Río Negro province and in a rural locality of Chubut province.

Financial support: Agencia Nacional de Promoción Científica y Tecnológica (BID 1201 OC-AR PICT 08830) and UBACYT, PID 2001-2002, EX 145

${ }^{+}$Corresponding author. Fax: +54-11-4576.3384. E-mail: fkleiman@bg.fcen.uba.ar

Received 28 October 2003

Accepted 9 January 2004
Snails were sampled in January, March, and November 2000, from a concrete pond of approximately $150 \times 50$ $\mathrm{m}$ (Fig. 2), placed in the main Public Square of El Bolsón Village ( $\left.41^{\circ} 58^{\prime} \mathrm{S}, 71^{\circ} 31^{\prime} \mathrm{O}\right)$, Río Negro province. In addition, snail collections were conducted in November 1999, and January, March, and November 2000 from marshes, lagoons, irrigation ditches, streams and temporary small ponds within a 2500-ha livestock establishment at the locality of Cholila ( $42^{\circ} 32^{\prime}$ 'S, $\left.71^{\circ} 34^{\prime} \mathrm{O}\right)$, northwest Chubut province (Fig. 1).

Both areas are located in the valleys of the Andean Patagonian region and belong to the Subantarctic phytogeographic province, Deciduous Forest district, which is

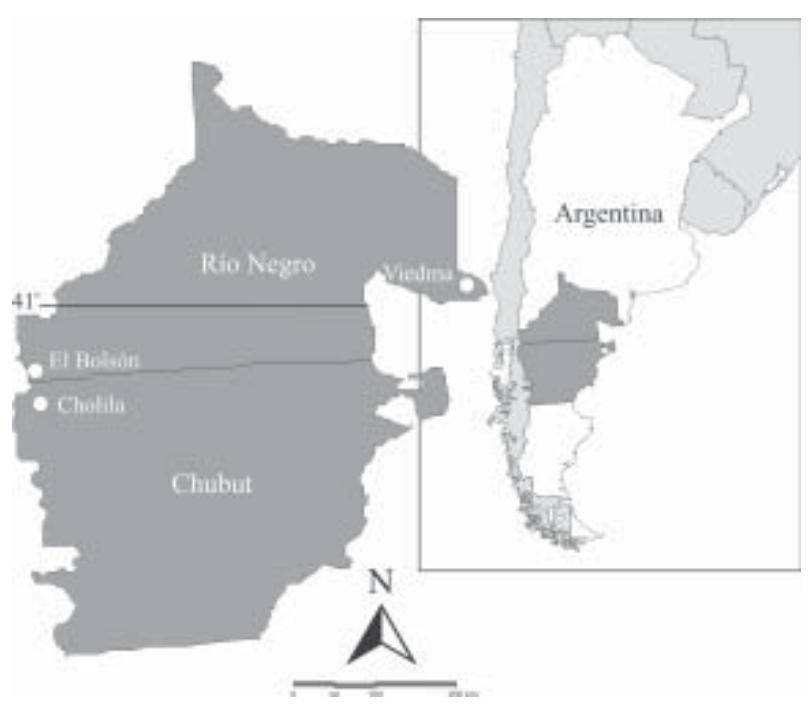

Fig. 1: map of part of Argentine Patagonia indicating the rural (Cholila) and urban (El Bolsón Village) studied areas and the former southernmost limit of Lymnaea viatrix (Viedma). 


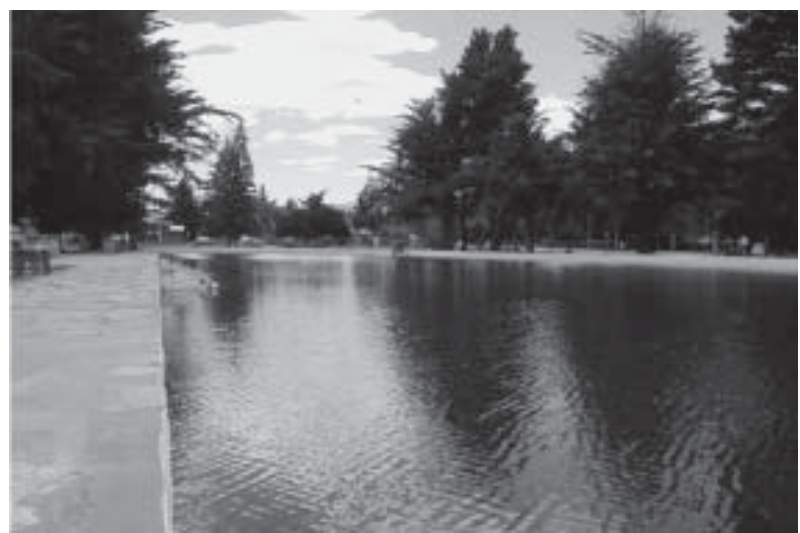

Fig. 2: view of the concrete pond in the Main Public Square of El Bolsón Village, Río Negro province, Argentine Patagonia.

characterized by temperate and humid climate (mean temperature: $9.5^{\circ} \mathrm{C}$, annual precipitation: $800 \mathrm{~mm}$ ) and forest and prairie as the dominant vegetation types (Cabrera \& Willink 1980).

Collected snails were placed alive between wet cotton layers in properly labelled plastic recipients. Upon arrival to the laboratory, six specimens from each waterbody were relaxed, killed, and preserved according to Paraense (1984) for taxonomic determination by features of the shell and reproductive organs (Paraense 1976, 1983, 1984). The rest of the individuals, identical in external appearance to those used for determination, were dissected under stereoscopic microscope to detect larvae of $F$. hepatica. To confirm taxonomical identity of the parasite, five metacercariae were orally administered to each of six Wistar rats 56 days old. Search of eggs in faeces was performed on day 60 postinfection and positive animals were sacrificed to check the presence of adults of $F$. hepatica in the bile ducts.

Throughout the study period, snails were found repeatedly in all surveyed waterbodies. A total of 811 snails were collected from the rural area and 90 from the urban area. All individuals belonged to L. viatrix.

Seven out of the $811(0.9 \%)$ snails collected in Cholila were infected with $F$. hepatica. Adult flukes were recovered from 2 out of 6 rats. In contrast, none of the snails from the artificial pond of El Bolson Village showed parasite larvae.

Our results increase the distribution range of L. viatrix that has previously been reported north of latitude $41^{\circ} \mathrm{S}$. The occurrence of this species in urban and natural waterbodies reflects its capacity to adapt to different environments, including man-made water reservoirs.

The fact that $L$. viatrix was the only lymnaeid species found in the rural area together with the assessment of infection by $F$. hepatica suggest that this snail species may represent the main intermediate host in the transmission cycle of the parasite in the Andean-Patagonian valleys.

The large artificial pond of El Bolsón may constitute a potential risk to public health. This pond is a main point of attraction for the approximately 13,000 permanent inhabitants (INDEC 2001) and for more than 50,000 international tourists visiting the village during summer. Snails and/or egg masses may have been introduced in the pond by passive transport via wetland plants or aquatic birds, to subsequently colonize the waterbody. This assumption is suggested by the large number of individuals recorded and their permanence over time.

To our knowledge, no information on the presence of L. viatrix in an urban environment has ever been reported. Further research is needed to evaluate the epidemiological importance of urban waterbodies that are inhabited by lymnaeids and are surrounded by rural endemic areas of fasciolosis, like the one studied here.

\section{ACKNOWLEDGEMENTS}

To Establecimiento Los Murmullos for providing valuable cooperation and field facilities, to Departamento de Microbiología, Parasitología e Inmunología de la Facultad de Medicina, Universidad de Buenos Aires, for technical assistance and laboratory facilities, and to Lucía Adler for valuable information.

\section{REFERENCES}

Cabrera AL, Willink A 1980. Biogeografía de América Latina, Monografía 13, Serie Biología, Organización de los Estados Americanos, Washington, $120 \mathrm{pp}$.

Castellanos Z, Landoni NA 1981. Mollusca, Gasteropoda, Lymnaeidae. In Fauna de Agua Dulce de la República Argentina (Vol. XV), FECIC, Buenos Aires, p. 55-76.

Hylton Scott MI 1953. Sobre limnaeidae argentinos (Mollusca, Pulmonata). Physis 20: 401-408

Hubendick B 1951. Recent Lymnaeidae: their variation, morphology, taxonomy nomenclature and distribution. Kungl Svensk Vetenskaps Handl 3: 1-223.

INDEC-Instituto Nacional de Estadísticas y Censos 2001. Secretaría de Planificación, Censo Nacional de Población y Vivienda, Repúbica Argentina.

Lombardero O, Moriena R, Racioppi O, Quiroz L 1979. Bionomía de Lymnaea sp. en la provincia de Corrientes. Veterinaria (Corrientes, Argentina) 2: 5-19.

Mas-Coma S, Angles R, Strauss W, Esteban JG, Oviedo JA, Buchon P 1995. Human fascioliasis in Bolivia: a general analysis and a critical review of existing data. Res Rev Parasitol 55: 73-79.

Mas-Coma MS, Esteban JG, Bargues MD 1999. Epidemiology of human fascioliasis: a review and proposed new classification. Bull WHO 77: 340-346.

Paraense WL 1976. Lymnaea viatrix: a study of topotypic specimens (Mollusca: Lymnaeidae). Rev Brasil Biol 36: 419-428.

Paraense WL 1982. Lymnaea viatrix and Lymnaea columella in the Neotropical region: a distributional outline. Mem Inst Oswaldo Cruz 77: 181-188.

Paraense WL 1983. Lymnaea columella in Northern Brazil. Mem Inst Oswaldo Cruz 78: 477-482.

Paraense WL 1984. Lymnaea diaphana: a study of topotypic specimens (Pulmonata: Lymnaeidae). Mem Inst Oswaldo Cruz 79: 75-81.

Prepelitchi L, Kleiman F, Pietrokovsky SM, Moriena RA, Racioppi O, Alvarez J, Wisnivesky C 2003. First report of Lymnaea columella Say, 1817 (Pulmonata: Lymnaeidae) naturally infected with Fasciola hepatica (Linnaeus, 1758) (Trematoda: Digenea) in Argentina. Mem Inst Oswaldo Cruz. 98: 889-891.

Rossanigo CE, Avila JD, Vasquez R, Sager RL 1983. Incidencia, distribución e identificación del huésped intermediario de la distomatosis bovina en la Provincia de San Luis. Gaceta Veterinaria (Buenos Aires) 382: 739-746.

Venturini L, Fonrouge R 1985. Lymnaea viator (D’Orbigny 1835): aspectos de su biología en condiciones naturales. Rev Méd Vet (Buenos Aires) 66: 340-345. 